\title{
Tyrphostin A48
}

National Cancer Institute

\section{Source}

National Cancer Institute. Tyrphostin A48. NCI Thesaurus. Code C2027.

A member of the Tyrphostin family of tyrosine kinase inhibitors that inhibits epidermal growth factor receptor tyrosine kinase. $(\mathrm{NCl})$ 